\title{
ON THE OCCURRENCE OF CEPHALOPHOLIS HEMISTIKTOS AND C. TAENIOPS (ACTINOPTERYGII, PERCIFORMES, SERRANIDAE) IN MALTA, WITH CORRECTIONS OF PREVIOUS MISIDENTIFICATIONS
}

\author{
Julian EVANS* and Patrick J. SCHEMBRI
}

Department of Biology, University of Malta, Msida MSD2080, Malta

\begin{abstract}
Evans J., Schembri P.J. 2017. On the occurrence of Cephalopholis hemistiktos and C. taeniops (Actinopterygii, Perciformes, Serranidae) in Malta, with corrections of previous misidentifications. Acta Ichthyol. Piscat. 47 (2): 197-200.
\end{abstract}

\begin{abstract}
The only species of Cephalopholis currently known from the Mediterranean is Cephalopholis taeniops (Valenciennes, 1828), which was recorded from Libya, Malta, and Lampedusa after having autochthonously extended its original Atlantic range. All records of Cephalopholis substantiated by specimens or images from Malta were evaluated, showing that an individual filmed in August 2009 was misidentified and instead represents the first record of Cephalopholis hemistiktos (Rüppell, 1830) from the Mediterranean. Based on these records, $C$. taeniops is considered to be established in Maltese waters while $C$. hemistiktos is regarded as a 'casual' species, most likely transported by shipping or introduced as an aquarium escapee.
\end{abstract}

Keywords: alien species, first record, Epinephelinae, central Mediterranean, newcomer

The number of newcomer fish species in the newcomer species recorded from Maltese waters (Evans Mediterranean Sea is steadily increasing (Galil et al. 2014). Seven non-indigenous species of Serranidae are currently included in the Mediterranean Science Commission's atlas of exotic fish (Golani et al. 2013): Cephalopholis taeniops (Valenciennes, 1828); Epinephelus coioides (Hamilton, 1822); Epinephelus fasciatus (Forsskål, 1775); Epinephelus malabaricus (Bloch et Schneider, 1804); Epinephelus merra Bloch, 1793; Mycteroperca fusca (Lowe, 1838); and Paranthias furcifer (Valenciennes, 1828). Another two groupers have been reported since then: Epinephelus areolatus (Forsskål, 1775) and Epinephelus geoffroyi (Klunzinger, 1870)** (Golani et al. 2015, Rothman et al. 2016 $\left.{ }^{* * *}\right)$. Only two of these non-indigenous groupers are known from the central Mediterranean. The African hind, C. taeniops, was first recorded from Libya in 2002 (Ben Abdallah et al. 2007), and subsequently reached Malta in 2008 (Schembri and Tonna 2011) and Lampedusa in 2009 (Guidetti et al. 2010), while the Malabar grouper, E. malabaricus, was recorded from Malta in 2011 (Schembri and Tonna 2011).

Consequently only two serranid species were included in the latest published list of non-native and other et al. 2015): E. malabaricus is considered a true alien species probably introduced into Malta via shipping, while Cephalopholis taeniops likely extended its range into the central Mediterranean autochthonously. However, while reviewing past records of $C$. taeniops from Malta we noted individuals that did not match the typical coloration pattern of this species, raising doubts as to their identification. Furthermore, Louisy (2015) included the yellowfin hind, Cephalopholis hemistiktos (Rüppell, 1830), in his guide to European and Mediterranean marine fish, stating it had been observed in Malta in 2009. We therefore searched for and evaluated all reports of species of Cephalopholis caught or photographed in Maltese waters to ascertain which species have actually been recorded and to assess their status.

The history of records of Cephalopholis from Malta makes an interesting tale. A short video clip of a species belonging to this genus, filmed in August 2009, was uploaded on YouTube on 2 September $2009^{* * * *}$. Images taken from this video were then published in FishBase (Froese and Pauly 2016) as Cephalopholis taeniops, having been submitted by user Alexander Buttigieg

\footnotetext{
* Correspondence: Dr. Julian Evans, Department of Biology, University of Malta, Msida MSD2080, Malta, phone: (+356) 23402789, fax: (+356) 21323781, e-mail: (JE) julian.evans@um.edu.mt, (PJS) patrick.j.schembri@um.edu.mt.

"Epinephelus geoffroyi (Klunzinger, 1870) is currently listed as a synonym of Epinephelus chlorostigma (Valenciennes, 1828) in the WoRMS database, citing Randall (1992) as the source of synonymy. However, Randall et al. (2013) have reinstated E. geoffroyi and distinguished it from E. chlorostigma through a number of morphological characteristics. Randall et al. (2013) also concluded that previous records of E. geoffroyi from the Red Sea were misidentified as E. chlorostigma. Based on the descriptions given in Randall et al. (2013), Golani et al. (2015) identified their specimen as E. geoffroyi, and we follow these authors in reporting it under this name.

*** Another serranid, Pseudanthias squamipinnis (Peters, 1855), was reported for the Mediterranean by Bitar (2013), but we have excluded it from our list based on the recommendation of one of the referees of the paper, who believes that this is a case of an obvious misidentification.

**** https://www.youtube.com/watch? $v=b f C a F i n 8 u D 8$
} 
on 22 September 2009. This finding was subsequently reported on in the local media (Vassallo 2009), again as $C$. taeniops, with additional details that the individual was filmed at a depth of around $40 \mathrm{~m}$ close to the Sliema coast (NE Malta). Two years later, Deidun et al. (2011) republished images of this individual, reporting it as the first record of $C$. taeniops from Maltese waters. These authors also gave details of a second record of $C$. taeniops from Malta made in January 2011 but did not include an image of their specimen, stating instead that it exhibited similar dimensions and livery to the first individual recorded for this species in Maltese waters. Yet another record of C. taeniops was mentioned by Schembri and Tonna (2011); this was based on a specimen caught in July 2008, which predates the sightings reported by Deidun et al. (2011) and hence represents the earliest known record for this species in Maltese waters. Given the three separate reports of C. taeniops between 2008 and 2011, Evans et al. (2015) considered this species to have probably established a population in Maltese waters, but commented that some doubt remains due to the absence of further, more recent, records.

Close examination of the records and supporting evidence gathered during the presently reported work suggests a different story (Table 1). The July 2008 specimen is supported by a photograph (Fig. 1) which clearly shows an orange-brown background colour with numerous blue spots having dark margins found all along the body, pectoral fins that are blackish distally and which have numerous blue spots on the base, and a horizontal blue line running from the snout to below the eye. These characters are diagnostic for Cephalopholis taeniops, confirming this as the first record of this species from Maltese waters (Heemstra and Randall 1993). On the other hand, the individual filmed in August 2009 had a different coloration pattern (see images in Deidun et al. 2011): the bluish spots appear lighter and are mostly restricted to the lower part of the head and body, the pectoral fins have a wide orange-yellow outer margin, a lighter pale yellowish area is present between the dorsal fin and the top of the caudal peduncle, and there is no blue line below the eye. These features do not agree with published descriptions of $C$. taeniops. Instead, these characters enable positive identification of $C$. hemistiktos (see Heemstra and Randall 1993), and in fact Louisy (2015) was referring to this same specimen when reporting a 2009 observation of C. hemistiktos from Malta (Patrick Louisy, personal communication, 2016). This calls into question the identity of the January 2011 specimen reported by Deidun et al. (2011); since these authors comment that it had a similar colour pattern to that of the individual filmed in August 2009 , then it is possible that it was also misidentified and was in fact $C$. hemistiktos. However, we were unable to trace a photograph of this specimen and therefore cannot ascertain the true identity of the reported fish.

Since past records of 'Cephalopholis taeniops' from Maltese waters actually referred to two different species, an evaluation of the status of both $C$. taeniops and the newly reported $C$. hemistiktos is necessary. The first record of the African hind remains that made in July 2008 (Fig. 1; Schembri and Tonna 2011), most likely having arrived in Maltese waters through natural range expansion. Although the specimens recorded in 2009 and 2011 do not belong to this species, during the presently reported work we uncovered another two recent records of $C$. taeniops. The first is a specimen caught and photographed by a local fisherman in December 2015 (Fig. 2). The anterior part of the head lay in the shade when the photo was taken, such that the blue line below the eye is not clearly visible in the image, but the other characters allow identification as

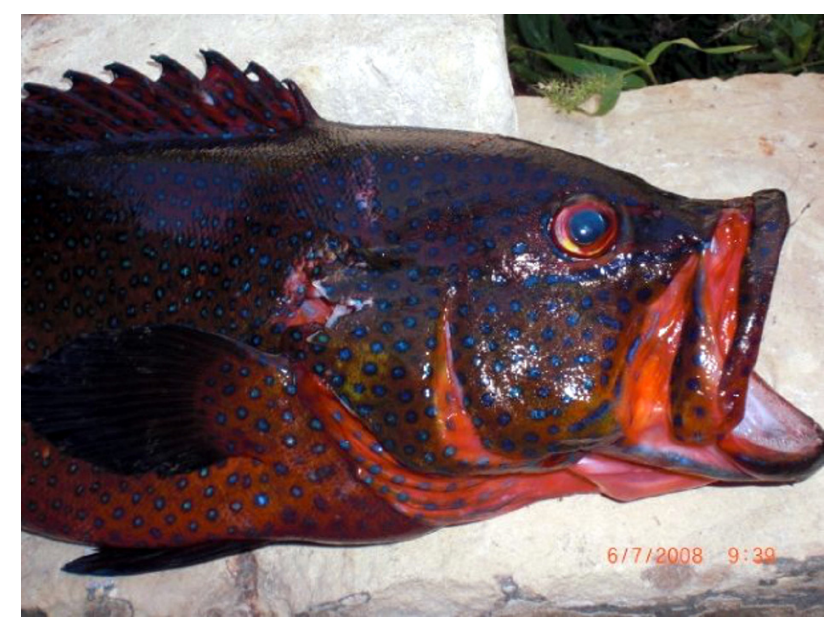

Fig. 1. A specimen of Cephalopholis taeniops caught in July 2008, representing the first record of this species from Maltese waters

Table 1

Records of species of Cephalopholis made in Maltese waters by August 2016, with corrections of previous misidentifications

\begin{tabular}{|c|c|c|c|c|}
\hline Date & $\begin{array}{c}\text { Original } \\
\text { Identification }\end{array}$ & Reference & Actual Identity & Notes \\
\hline July 2008 & C. taeniops & $\begin{array}{l}\text { Schembri and } \\
\text { Tonna } 2011\end{array}$ & C. taeniops & $\begin{array}{l}\text { Confirmed first record of C. taeniops from } \\
\text { Maltese waters }\end{array}$ \\
\hline August 2009 & C. taeniops & Deidun et al. 2011 & C. hemistiktos & First Mediterranean record of $C$. hemistiktos \\
\hline January 2011 & C. taeniops & Deidun et al. 2011 & ? & $\begin{array}{l}\text { Unauthenticated record; identity cannot be } \\
\text { ascertained in absence of a photograph }\end{array}$ \\
\hline December 2015 & C. taeniops & Present work & C. taeniops & Additional authenticated record \\
\hline July 2016 & C. taeniops & Present work & C. taeniops & Additional authenticated record \\
\hline
\end{tabular}


C. taeniops; the only other species with similar coloration pattern is Cephalopholis miniata (Forsskål, 1775), but this species has few or no blue spots on the pectoral fin base (Louisy 2015). Another specimen of C. taeniops was filmed in Malta in July 2016 (Fig. 3). The distribution of blue spots on the entire body and the blue line from the snout to below the eye are clearly visible in the footage, and we therefore consider this to be another authenticated record of the species. This specimen appears to have a dark background colour, but this is likely due to the absence of strong artificial lighting as described in Guidetti et al. (2010). These two recent records indicate that $C$. taeniops is in fact established in Maltese waters.

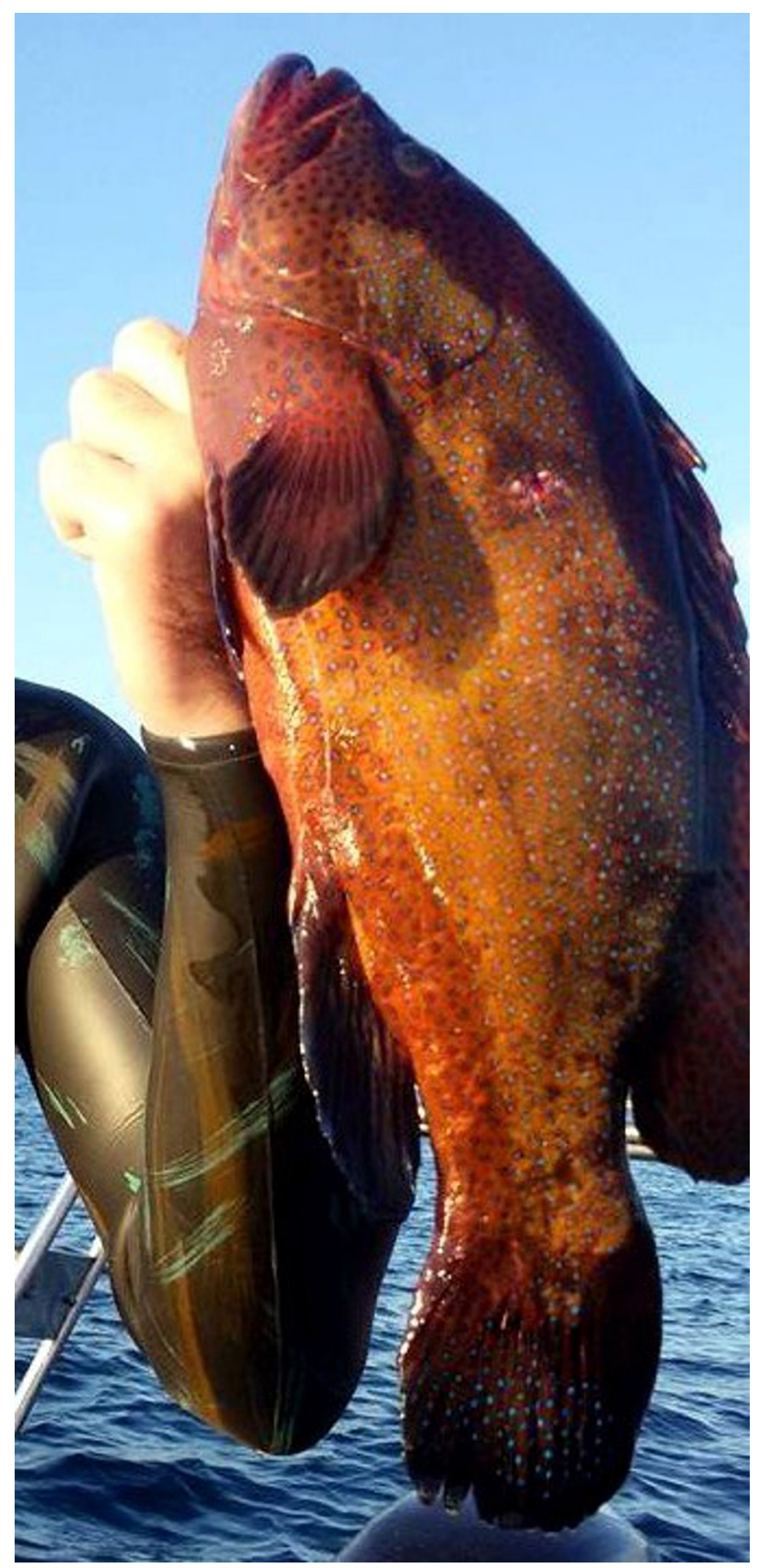

Fig. 2. A specimen of Cephalopholis taeniops caught in December 2015, indicating that this species is established in Maltese waters
In the case of Cephalopholis hemistiktos, the individual observed in August 2009 represents the first sighting of this Red Sea species in the Mediterranean, and the only authenticated record to date. Its status must therefore be regarded as 'casual'. Louisy (2015) remarked that it was probably introduced as an aquarium or aquaculture escapee; this was based on the fact that in the photographs published by Deidun et al. (2011), the specimen had a slightly 'swollen' appearance, which often happens to old fish grown for a long time in aquaria (Patrick Louisy, personal communication, 2016). However, we are not aware of any attempts to culture this species in Malta or nearby. While an aquarium release may be possible, it may have also reached Maltese waters through shipping, either as a stowaway in a sea-chest or similar waterfilled compartment in a large vessel, or by travelling in association with the fouling growth on the hull of a slowmoving vessel such as a barge or a drilling platform, as discussed in the case of Oplegnathus fasciatus (Temminck et Schlegel, 1844) (see Schembri et al. 2010).

Reliable species identification is one of the top issues for management of marine alien species in Europe (Ojaveer et al. 2014). The presently reported work highlights the need for authors and reviewers to exercise caution and check identifications carefully, especially if these are based solely on photographs or video footage. Images taken by sea-users are undoubtedly very useful as first alerts to the occurrence of new species or to changes in distribution, but without supporting specimens such photographs need to be assessed carefully and any doubts in the identification highlighted and discussed, rather than dismissed or not commented upon. This is especially true for species that resemble each other closely, and particularly when the record is based on field images, since these are unlikely to be laid out as museum specimens or to show clearly key identification features.

\section{ACKNOWLEDGEMENTS}

We are grateful to Dr. Patrick Louisy (Laboratoire ECOMERS, Université de Nice-Sophia Antipolis) for confirming the source of the record of Cephalopholis

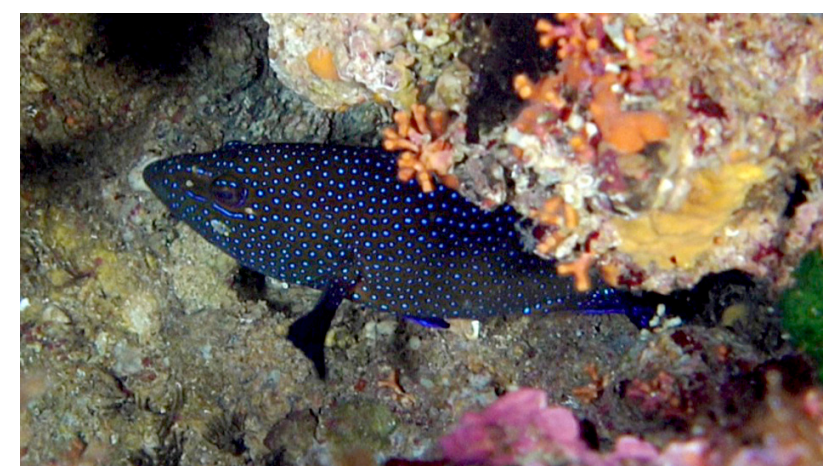

Fig. 3. A specimen of Cephalopholis taeniops, extracted from video footage collected in July 2016, which confirms that this species is established in Maltese waters (Image source: OCEANA/Enrique Talledo (C) LIFE BaHAR for N2K) 
hemistiktos from Malta listed in his book and for providing additional information on this species. The video footage of the $C$. taeniops specimen filmed in July 2016 was brought to our attention by Silvia Garcia (Fundación Oceana); the footage was collected as part of the LIFE BaHAR for N2K (LIFE12 NAT/MT/000845) Project, which is 50\% co-financed by the EU LIFE+ Funding Programme and implemented by the Maltese Environment and Resources Authority (ERA), the University of Malta, Fundación Oceana, the Ministry for Sustainable Development, the Environment and Climate Change (MSDEC), and the Department for Fisheries and Aquaculture within MSDEC. We are also thankful to Prof. Patrice Francour (Laboratoire ECOMERS, Université de Nice-Sophia Antipolis) and an anonymous referee for their comments on an earlier draft of this manuscript.

\section{REFERENCES}

Ben Abdallah A., Ben Souissi J., Méjri H., Capapé C., Golani D. 2007. First record of Cephalopholis taeniops (Valenciennes) in the Mediterranean Sea. Journal of Fish Biology 71 (2): 610-614. DOI: $10.1111 / \mathrm{j} .1095-8649.2007 .01504 . \mathrm{x}$

Bitar G. 2013. Sur la presence des poissons exotiques nouveaux de la cote Libanaise (Mediterranee orientale). Rapport du Congrès de la Commission Internationale pour l'Exploration Scientifique de la Mer Méditerranée 40: 592.

Deidun A., Castriota L., Arrigo S. 2011. A tale of two Atlantic fish migrants: Records of the lesser amberjack Seriola fasciata and the African hind Cephalopholis taeniops from the Maltese Islands. Journal of the Black Sea/Mediterranean Environment 17 (3): 223-233.

Evans J., Barbara J., Schembri P.J. 2015. Updated review of marine alien species and other 'newcomers' recorded from the Maltese Islands (Central Mediterranean). Mediterranean Marine Science 16 (1): 225-244.

DOI: $10.12681 / \mathrm{mms} .1064$

Froese R., Pauly D. (eds.) 2016. FishBase. [Version 06/2016] www.fishbase.org

Galil B.S., Marchini A., Occhipinti-Ambrogi A., Minchin D., Narščius A., Ojaveer H., Olenin S. 2014. International arrivals: Widespread bioinvasions in European seas. Ethology Ecology and Evolution 26 (2-3): 152-171.

DOI: $10.1080 / 03949370.2014 .897651$

Golani D., Askarov G., Dashevsky Y. 2015. First record of the Red Sea spotted grouper, Epinephelus geoffroyi (Klunzinger, 1870) (Serranidae) in the Mediterranean. BioInvasions Records 4 (2): 143-145.

DOI: 10.3391/bir.2015.4.2.12
Golani D., Orsi-Relini L., Massuti E., Quignard J.-P., Dulčić J., Azzurro E. 2013. CIESM atlas of exotic fishes in the Mediterranean. Check-list of exotic species. http://www.ciesm.org/atlas/appendix1.html [Accessed 25 August 2016.]

Guidetti P., Giardina F., Azzurro E. 2010. A new record of Cephalopholis taeniops in the Mediterraean Sea, with considerations on the Sicily Channel as a biogeographical crossroad of exotic fish. Marine Biodiversity Records 3: e13. DOI: $\underline{10.1017 / \mathrm{s} 1755267210000023}$

Heemstra P.C., Randall J.E. 1993. FAO species catalogue Vol. 16. Groupers of the world (family Serranidae, subfamily Epinephelinae): an annotated and illustrated catalogue of the grouper, rockcod, hind, coral grouper, and lyretail species known to date. FAO, Rome.

Louisy P. 2015. Europe and Mediterranean marine fish identification guide. Les Éditions Eugen Ulmer, Paris.

Ojaveer H., Galil B.S., Gollasch S., Marchini A., Minchin D., Occhipinti-Ambrogi A., Olenin S. 2014. Identifying the top issues of marine invasive alien species in Europe. Management of Biological Invasions 5 (2): 81-84. DOI: $10.3391 / \mathrm{mbi} .2014 .5 .2 .01$

Randall J.E. 1992. Red Sea reef fishes. Immel Publishing, London, UK.

Randall J.E., Bogorodsky S.V., Krupp F., Rose J.M., Fricke R. 2013. Epinephelus geoffroyi (Klunzinger, 1870) (Pisces: Serranidae), a valid species of grouper endemic to the Red Sea and Gulf of Aden. Zootaxa 3641 (5): 524-532.

DOI: $10.11646 /$ zootaxa.3641.5.2

Rothman S.B.S., Stern N., Goren M. 2016. First record of the Indo-Pacific areolate grouper Epinephelus areolatus (Forsskål, 1775) (Perciformes: Epinephelidae) in the Mediterranean Sea. Zootaxa 4067 (4): 479-483.

DOI: $10.11646 /$ zootaxa.4067.4.7

Schembri P.J., Bodilis P., Evans J., Francour P. 2010. Occurrence of barred knifejaw, Oplegnathus fasciatus (Actinopterygii: Perciformes: Oplegnathidae), in Malta (central Mediterranean) with a discussion on possible modes of entry. Acta Ichthyologica et Piscatoria 40 (2): 101-104. DOI: 10.3750/AIP2010.40.2.01

Schembri P.J., Tonna R. 2011. Occurrence of the Malabar grouper Epinephelus malabaricus (Bloch et Schneider, 1801) (Actinopterygii, Perciformes, Serranidae), in the Maltese Islands. Aquatic Invasions 6 (Suppl. 1): S129-S132. DOI: 10.3391/ai.2011.6.S1.029

Vassallo R. 2009. New fish found as Med warms up. Malta Today (23 September 2009). http://archive. maltatoday.com.mt/2009/09/23/t6.html

Received: 29 August 2016

Accepted: 3 March 2017

Published electronically: 30 June 2017 